\title{
Diabetic Emergencies presenting during the COVID- 19 Pandemic: A Retrospective Case Analysis
}

Tobin Joseph ( $\nabla$ t.joseph@doctors.org.uk)

University College Hospital

Eleanor Crawley

Royal Free London NHS Foundation Trust

\section{Sulmaaz Qamar}

University College Hospital

\section{Maya Zosmer}

North Middlesex Hospital

Girish Rayanagoudar

North Middlesex Hospital

Chidambaram Nethaji

North Middlesex Hospital

Ravi Menon

North Middlesex Hospital

\section{Research Article}

Keywords: diabetic emergencies, COVID-19, SARS-COV-2, metabolic disturbances, diabetic patients

Posted Date: February 10th, 2021

DOI: https://doi.org/10.21203/rs.3.rs-149446/v1

License: (c) (i) This work is licensed under a Creative Commons Attribution 4.0 International License.

Read Full License

Version of Record: A version of this preprint was published at Endocrinology, Diabetes \& Metabolism on October 29th, 2021. See the published version at https://doi.org/10.1002/edm2.313. 


\section{Abstract}

\section{Introduction}

COVID-19 has triggered a global pandemic and is an emerging situation. Diabetes has been associated with significant mortality in SARS and MERS- COV infections. Patients with diabetes are at risk of COVID19 triggering diabetic emergencies due to known and unknown mechanisms. There is little evidence overviewing the clinical course of COVID19 patients who either present or have diabetic emergencies during their disease course.

\section{Methods}

We conducted a retrospective case analysis of all patients admitted to our hospital during the COVID-19 pandemic. The inclusion criteria were all patients receiving treatment for COVID-19 and either presenting with a diabetic emergency on admission or developing an emergency during their admission. Data collected for the study were all routinely collected data as part of the admission. We compared this data to 9 patients with no COVID-19.

\section{Results}

30 patients received treatment for a diabetic emergency, of which 21 also received treatment for COVID19. Significant differences were found between $\mathrm{pH}$ and bicarbonate on admission between RT-PCR positive and both RT-PCR negative and non-COVID-19 patients. Other results approaching significance include ALP and eGFR.

\section{Discussion}

Little is known about the metabolic disturbances COVID-19 has on diabetic patients. Further, prospective detailed investigation into biochemical processes is needed to elucidate underlying mechanisms that affect these patients' outcomes.

\section{Introduction}

Severe Acute Respiratory Syndrome Coronavirus 2 (SARS-COV-2) is a novel coronavirus that has triggered a global pandemic of which the current trajectory remains uncertain. Early data suggests that increasing age and cardiovascular disease are the markers for severity and mortality of the Coronavirus Disease 2019 (COVID-19) disease (1). A third of deaths in the United Kingdom with COVID-19 occurred in people with diabetes: $31 \cdot 4 \%$ in people with type 2 diabetes, $1.5 \%$ in those with type 1 diabetes, and $0.3 \%$ in people with other types of diabetes(2). Recent epidemiological studies have suggested that risk of mortality in COVID-19 can be up to 50\% higher in patients with diabetes (2), and a recent review has suggested that obese patients are at high risk of mortality from COVID-19. Hyperglycaemia and a known history of diabetes were independent predictors of death in a large cohort of patients with SARS-COV (3), further suggesting that diabetes could be of significance in the disease course of COVID-19. A recent 
meta-analysis also showed that diabetes is associated with mortality, severe COVID-19 acute respiratory distress syndrome (ARDS) and disease progression (4).

Bornstein et al recently published a consensus statement on the management of diabetes with COVID-19 and suggested that there could be an increase in Diabetic Ketoacidosis (DKA) in type 1 diabetics (T1DM) and type 2 diabetics (T2DM) on sodium glucose cotransporter inhibitors (SGLT2). They also report that there is an increased frequency DKA presentations, which might partly be due to delayed presentation (5). Diabetes UK have also recently published guidelines on the management of both hyperglycaemia and DKA, that includes advice to stop metformin and SGLT2 inhibitors for all suspected COVID-19 with diabetics (6).

Diabetic emergencies most associated with infection are DKA and Hyperglycaemic Hyperosmolar State (HHS) $(5,7)$. A recent study from China has shown that COVID-19 does cause ketosis and ketoacidosis requiring prolonged hospital admission. Interestingly ketosis was present in both patients with and without diabetes, and the reported data does not distinguish between Type 1 and Type 2 diabetics (11). The CORONADO study, investigating the phenotypic characteristics and prognosis of diabetes patients with COVID-19, suggested that younger, type 1 diabetes patients have a lower risk of severe COVID-19 prognosis (8).

There is very little evidence available regarding the management of diabetic patients who are also suffering from COVID-19. Uncontrolled hyperglycaemia and diabetes, of either type, were recognised as significant risk factors for both severity and mortality for different viruses, including other novel coronaviruses akin to COVID-19 (9).

Our aim was to report on the incidence, clinical course and outcomes from our cohort of diabetic patients that are being hospitalized for COVID-19.

\section{Methods}

We conducted a retrospective case analysis of diabetic patients admitted to the medical wards of North Middlesex Hospital, London, during the COVID-19 pandemic between 15th March up to 15th April 2020. The inclusion criteria were: 1) positive swab testing for COVID-19, 2) admission due to a diabetic emergency. We recorded details regarding the length of hospital stay, features of the metabolic emergency, time until resolution, treatment pathways utilized, clinical course of the patient, clinical outcome at 7 days post admission. Data for the study were extracted from routine hospital records. Notes were manually reviewed for results as well as for follow up information. The study was part of a departmental audit, evaluating treatment pathways for patients with diabetic emergencies during the pandemic, and has been approved by the Ethics Department of our Hospital.

\section{Diagnosis of COVID-19}


Primarily patients with clinical features matching the UK government case definition for COVID-19 (10), or patients that had biochemical/radiological features of COVID-19 received one COVID-19 PCR swab at the time of admission. During the time of this study, our local policy was not to re-swab patients if the PCR swab result was negative, despite a high clinical suspicion. Clinical suspicion was based on symptomatic, biochemical or radiological evidence consistent with COVID-19.

\section{Control group}

We also had a group of patients that underwent treatment for a diabetic emergency without being investigated or treated for COVID-19. These patients were used as comparators to investigate significant metabolic differences.

\section{Statistical Analysis}

Data was stored on a custom, anonymised Microsoft Excel 2010 (Microsoft, Richmond VA) database. Statistical analysis was done using Statistical Package for Social Sciences version 25.0 (SPSS). Qualitative characteristics were presented as mean values \pm standard deviation while quantitative characteristics were presented as percentages (\%). Differences between groups were evaluated using independent student t-test. Statistical significance was set at the level of $p$-value $<0.05$. We have split the patients into RT-PCR swab positive, and RT-PCR swab negative but treated with a high clinical suspicion. Kaplan-Meier survival graph was calculated based on length of stay in days for the three patient groups with death as the event.

\section{Results}

30 patients are included in this retrospective analysis, with their demographics demonstrated in Table 1. $21(70 \%)$ of these patients received treatment for both COVID-19 and a diabetic emergency during their admission. 2 patients with COVID-19 needed an ITU admission, one of whom died. This mortality was also COVID-19 RT-PCR swab positive.

14 out of 30 included patients were RT-PCR positive patients. 79\% $(n=2)$ had Type 2 Diabetes. 86\% $(n=$ 12) of RT-PCR patients were males and $14 \%(n=2)$ females with average age of $51.47 \pm 17.30$ years. 5 patients presented with DKA, 1 with HHS, 3 with a mixed DKA/HHS picture and 5 with hyperglycaemic ketosis. In terms of ethnicity, there were patients that were African $(n=5)$, White British $(n=1)$, Caucasian and Asian (including eastern and southern asia) $(n=6) .47 \%$ of RT-PCR patients were discharged home within 7 days.

7 patients were RT-PCR negative but treated for COVID-19 due to high degree of clinical suspicion. The average age was $47.33 \pm 20.46$ years, with 5 males and 2 females. $43 \%$ of these patients had Type 1 diabetes. 1 patient had DKA, 2 had HHS, 2 had a mixed picture with one patient having hyperglycaemic ketosis. $67 \%$ of patients had been successfully discharged home within 7 days. 
For the patients that were not treated for COVID-19 $(n=9)$, all patients had DKA despite the fact that $33 \%$ had Type 2 diabetes. There were 4 males and 5 females. $67 \%(n=6)$ of these patients were insulin treated, and $100 \%$ were discharged home within 7 days of admission. 
Table 1

Baseline Demographics of all patients that were management for both a diabetic emergency and COVID19 , including destination at 7 days

\begin{tabular}{|c|c|c|c|}
\hline & $\begin{array}{l}\text { COVID-19 Swab } \\
\text { Positive }(n=14)\end{array}$ & $\begin{array}{l}\text { COVID-19 Swab Negative, High } \\
\text { Clinical Suspicion of COVID-19 } \\
(n=7)\end{array}$ & $\begin{array}{l}\text { Non COVID-19 } \\
\text { patients }(n=9)\end{array}$ \\
\hline $\begin{array}{l}\text { Age (years), mean } \\
\pm \text { SD }\end{array}$ & $51.21 \pm 17.92$ & $47.33 \pm 20.46$ & $42.00 \pm 18.83$ \\
\hline \multicolumn{4}{|l|}{ Gender, n (\%) } \\
\hline Male & $12(85.7)$ & $5(71.4)$ & $4(44.4)$ \\
\hline Female & $2(14.3)$ & $2(28.6)$ & $5(55.6)$ \\
\hline \multicolumn{4}{|l|}{ Ethnicity, n (\%) } \\
\hline African & $4(28.6)$ & $4(57.1)$ & $2(22.2)$ \\
\hline Asian & $4(28.6)$ & $1(14.2)$ & $0(0.0)$ \\
\hline White British & $1(7.1)$ & $1(14.2)$ & $4(44.4)$ \\
\hline Caucasian & $3(21.4)$ & $1(14.2)$ & $3(33.3)$ \\
\hline Mixed & $1(7.1)$ & $0(0.0)$ & $0(0.0)$ \\
\hline Unknown & $1(7.1)$ & $0(0.0)$ & $0(0.0)$ \\
\hline \multicolumn{4}{|l|}{$\begin{array}{l}\text { Diabetic Diagnosis, } \\
\text { n (\%) }\end{array}$} \\
\hline Type 1 & $1(7.1)$ & 3 (42.9) & $5(55.6)$ \\
\hline Type 2 & $11(78.6)$ & $4(57.1)$ & $4(44.4)$ \\
\hline $\begin{array}{l}\text { New Diagnosis, } n \\
(\%)\end{array}$ & $1(7.1)$ & $0(0.0)$ & \\
\hline \multicolumn{4}{|l|}{$\begin{array}{l}\text { Diabetic } \\
\text { Emergency, n (\%) }\end{array}$} \\
\hline DKA & $5(35.7)$ & $1(14.2)$ & $9(100.0)$ \\
\hline HHS & $1(7.1)$ & $2(28.6)$ & $0(0.0)$ \\
\hline Mixed DKA/HHS & $3(21.4)$ & $1(14.2)$ & $0(0.0)$ \\
\hline $\begin{array}{l}\text { Hyperglycaemic } \\
\text { Ketosis }\end{array}$ & $5(35.7)$ & $1(14.2)$ & $0(0.0)$ \\
\hline $\begin{array}{l}\text { Redeveloped } \\
\text { Emergency }\end{array}$ & $0(0.0)$ & $0(0.0)$ & $0(0.0)$ \\
\hline
\end{tabular}




\begin{tabular}{|c|c|c|c|}
\hline & $\begin{array}{l}\text { COVID-19 Swab } \\
\text { Positive }(n=14)\end{array}$ & $\begin{array}{l}\text { COVID-19 Swab Negative, High } \\
\text { Clinical Suspicion of COVID-19 } \\
(n=7)\end{array}$ & $\begin{array}{l}\text { Non COVID-19 } \\
\text { patients }(n=9)\end{array}$ \\
\hline \multicolumn{4}{|l|}{$\begin{array}{l}\text { Pre-Admission } \\
\text { Medication, } \mathrm{n}(\%)\end{array}$} \\
\hline Metformin & $8(57.1)$ & $5(71.4)$ & 3 (33.3) \\
\hline DDP4 inhibitors & $1(7.1)$ & $1(14.2)$ & $1(11.1)$ \\
\hline Insulin & $7(50.0)$ & $3(42.9)$ & $6(66.7)$ \\
\hline $\begin{array}{l}\text { Other } \\
\text { hypoglycaemics }\end{array}$ & $4(28.6)$ & $2(28.6)$ & $1(11.1)$ \\
\hline $\begin{array}{l}\text { No prior } \\
\text { medication/Diet } \\
\text { controlled }\end{array}$ & $4(28.6)$ & $1(14.2)$ & $0(0.0)$ \\
\hline $\begin{array}{l}\text { ITU Admissions, n } \\
(\%)\end{array}$ & $2(14.3)$ & $1(14.2)$ & $2(22.2)$ \\
\hline \multicolumn{4}{|l|}{$\begin{array}{l}\text { Destination at } 7 \\
\text { days, } \mathrm{n}(\%)\end{array}$} \\
\hline Discharged & $5(35.7)$ & $6(85.7)$ & $9(100.0)$ \\
\hline Ward & $7(50.0)$ & $0(0.0)$ & $0(0.0)$ \\
\hline ITU & $1(7.1)$ & $0(0.0)$ & $0(0.0)$ \\
\hline Died & $1(7.1)$ & $1(14.2)$ & $0(0.0)$ \\
\hline
\end{tabular}

DKA - diabetic ketoacidosis; HHS - Hyperosmolar Hyperglycaemic State; Other oral hypoglycaemics include sulfonylureas, glucagon like peptide 1 agonists

Table 2 demonstrates the admission gas results, blood tests and glycosylated haemoglobin (HbA1c) as well as selected COVID-19 markers. Broadly routine admission blood tests were similar when averaged and compared between the three groups. There was a non-significant rise in white cell count going from the RT-PCR patients to non-COVID-19 patients. No significant lymphopenia was observed between any of the three groups.

Admission $\mathrm{pH}$ was not significantly different between RT-PCR positive and negative patients $(\mathrm{p}=0.533)$, however there was a significant difference between RT-PCR positive COVID-19 patients and our nonCOVID-19 patients $(p=0.028)$. There was a significant difference between RT-PCR positive COVID-19 patients and our non-COVID-19 patients with regards to HCO3 $(p=0.04)$. There was a significant difference in the C-Reactive Protein $(p=0.026)$ and Glucose $(p=0.045)$ between RT-PCR positive and negative patients. 
Kaplan-Meier survival curves were drawn for the groups, comparing all-cause mortality. This is shown in Fig. 1. It demonstrates that the cumulative survival time drops if being treated for COVID-19, and more so if treated for COVID yet RT-PCR negative. 
Table 2

Admission Blood test results including some COVID-19 markers

\begin{tabular}{|c|c|c|c|c|c|c|}
\hline $\begin{array}{l}\text { Blood test result } \\
\text { mean } \pm S D\end{array}$ & $\begin{array}{l}\text { COVID-19 } \\
\text { Swab } \\
\text { Positive } \\
(n=14)\end{array}$ & $\begin{array}{l}\text { COVID-19 Swab } \\
\text { Negative, High } \\
\text { Clinical Suspicion } \\
\text { of COVID-19 }(n= \\
7)\end{array}$ & $\begin{array}{l}\text { COVID-19 Swab } \\
\text { Negative, Low } \\
\text { Clinical Suspicion } \\
\text { of COVID-19 }(n= \\
\text { 9) }\end{array}$ & $p^{a}$ & $p^{b}$ & $p^{c}$ \\
\hline $\begin{array}{l}\text { Admission Blood } \\
\text { glucose }(\mathrm{mmol} / \mathrm{l})\end{array}$ & $\begin{array}{l}23.86 \pm \\
8.38\end{array}$ & $33.29 \pm 11.49$ & $26.34 \pm 12.47$ & 0.045 & 0.573 & 0.272 \\
\hline $\begin{array}{l}\text { Serum Ketones } \\
(\mathrm{mmol} / \mathrm{l})\end{array}$ & $\begin{array}{l}4.44 \pm \\
2.53\end{array}$ & $5.6 \pm 2.51$ & $5.67 \pm 0.99$ & 0.314 & 0.154 & 0.943 \\
\hline $\begin{array}{l}\text { Time for ketone } \\
\text { resolution (hours) }\end{array}$ & $\begin{array}{l}43.10 \pm \\
44.01\end{array}$ & $25.70 \pm 15.81$ & $28.44 \pm 20.60$ & 0.413 & 0.378 & 0.794 \\
\hline $\begin{array}{l}\text { Admission HbA1c } \\
(\mathrm{mmol} / \mathrm{mol})\end{array}$ & $\begin{array}{l}115.30 \pm \\
42.85\end{array}$ & $91.83 \pm 12.27$ & $109.75 \pm 46.95$ & 0.217 & 0.834 & 0.387 \\
\hline $\begin{array}{l}\text { Pre admission } \\
\text { HbA1c }\end{array}$ & $\begin{array}{l}99.38 \pm \\
31.18\end{array}$ & $70.60 \pm 39.76$ & $73.33 \pm 15.70$ & 0.131 & 0.210 & 0.893 \\
\hline \multicolumn{7}{|l|}{$(\mathrm{mmol} / \mathrm{mol})$} \\
\hline $\begin{array}{l}\text { Haemoglobin } \\
(\mathrm{g} / \mathrm{l})\end{array}$ & $\begin{array}{l}139.92 \pm \\
24.63\end{array}$ & $143.86 \pm 18.45$ & $134.67 \pm 39.42$ & 0.717 & 0.703 & 0.580 \\
\hline WCC $\left(\times 10^{9} / I\right)$ & $\begin{array}{l}10.06 \pm \\
3.46\end{array}$ & $10.37 \pm 4.16$ & $12.54 \pm 4.31$ & 0.857 & 0.149 & 0.328 \\
\hline Platelets $\left(\times 10^{9} / \mathrm{I}\right)$ & $\begin{array}{l}281.08 \pm \\
94.39\end{array}$ & $283.71 \pm 76.84$ & $296.44 \pm 103.53$ & 0.950 & 0.722 & 0.790 \\
\hline $\begin{array}{l}\text { Lymphocytes } \\
\left(\times 10^{9} / \mathrm{I}\right)\end{array}$ & $\begin{array}{l}1.25 \pm \\
0.55\end{array}$ & $1.32 \pm 0.77$ & $1.26 \pm 0.95$ & 0.814 & 0.953 & 0.909 \\
\hline Sodium $(\mathrm{mmol} / \mathrm{l})$ & $\begin{array}{l}141.08 \pm \\
13.08\end{array}$ & $155.43 \pm 38.33$ & $134.11 \pm 9.07$ & 0.229 & 0.183 & 0.126 \\
\hline $\begin{array}{l}\text { Potassium } \\
(\mathrm{mmol} / \mathrm{l})\end{array}$ & $\begin{array}{l}5.28 \pm \\
0.82\end{array}$ & $5.51 \pm 1.13$ & $5.22 \pm 1.35$ & 0.601 & 0.913 & 0.653 \\
\hline Urea (mmol/l) & $\begin{array}{l}13.41 \pm \\
12.73\end{array}$ & $15.47 \pm 6.74$ & $15.16 \pm 13.16$ & 0.696 & 0.758 & 0.955 \\
\hline $\begin{array}{l}\text { Creatinine } \\
\text { (micromoles/litre) }\end{array}$ & $\begin{array}{l}183.77 \pm \\
186.70\end{array}$ & $179.71 \pm 48.96$ & $122.67 \pm 52.29$ & 0.956 & 0.354 & 0.043 \\
\hline eGFR & $\begin{array}{l}53.67 \pm \\
30.09\end{array}$ & $41.86 \pm 16.38$ & $73.22 \pm 27.25$ & 0.224 & 0.580 & 0.089 \\
\hline CRP (mg/l) & $\begin{array}{l}88.32 \pm \\
68.07\end{array}$ & $26.83 \pm 24.35$ & $57.40 \pm 123.91$ & 0.026 & 0.459 & 0.485 \\
\hline Ferritin (ng/ml) & $\begin{array}{l}1321 \pm \\
1015.79\end{array}$ & $921.67 \pm 432.28$ & - & & & \\
\hline
\end{tabular}




\begin{tabular}{|c|c|c|c|c|c|c|}
\hline $\begin{array}{l}\text { Blood test result } \\
\text { mean } \pm S D\end{array}$ & $\begin{array}{l}\text { COVID-19 } \\
\text { Swab } \\
\text { Positive } \\
(n=14)\end{array}$ & $\begin{array}{l}\text { COVID-19 Swab } \\
\text { Negative, High } \\
\text { Clinical Suspicion } \\
\text { of COVID-19 }(n= \\
7)\end{array}$ & $\begin{array}{l}\text { COVID-19 Swab } \\
\text { Negative, Low } \\
\text { Clinical Suspicion } \\
\text { of COVID-19 }(n= \\
9)\end{array}$ & $p^{a}$ & $p^{b}$ & $p^{c}$ \\
\hline LDH (U/L) & $\begin{array}{l}391.60 \pm \\
227.32\end{array}$ & $414.33 \pm 164.69$ & - & & & \\
\hline $\begin{array}{l}\text { Bilirubin } \\
\text { (micromole/litre) }\end{array}$ & $\begin{array}{l}5.85 \pm \\
3.34\end{array}$ & $6.43 \pm 3.60$ & $7.00 \pm 4.64$ & 0.721 & 0.504 & 0.792 \\
\hline ALT (iu/l) & $\begin{array}{l}34.00 \pm \\
49.96\end{array}$ & $28.85 \pm 11.87$ & $25.50 \pm 16.03$ & 0.452 & 0.244 & 0.657 \\
\hline ALP (iu/L) & $\begin{array}{l}92.23 \pm \\
32.24\end{array}$ & $86.14 \pm 46.52$ & $125.67 \pm 60.13$ & 0.734 & 0.106 & 0.174 \\
\hline CK (U/L) & $\begin{array}{l}2033.50 \\
\pm \\
2035.76\end{array}$ & & & & & \\
\hline INR & $\begin{array}{l}1.87 \pm \\
2.28\end{array}$ & $1.10 \pm 0.09$ & $1.07 \pm 0.07$ & 0.434 & 0.411 & 0.415 \\
\hline PT & $\begin{array}{l}17.87 \pm \\
19.24\end{array}$ & $11.48 \pm 0.92$ & $11.27 \pm 0.68$ & 0.437 & 0.422 & 0.653 \\
\hline APTT & $\begin{array}{l}37.00 \pm \\
24.89\end{array}$ & $27.833 \pm 4.26$ & $31.00 \pm 3.29$ & 0.395 & 0.572 & 0.180 \\
\hline \multicolumn{7}{|l|}{ Blood Gas } \\
\hline $\mathrm{pH}$ & $\begin{array}{l}7.24 \pm \\
0.17\end{array}$ & $7.18 \pm 0.22$ & $7.06 \pm 0.18$ & 0.533 & 0.028 & 0.263 \\
\hline HCO3- & $\begin{array}{l}15.79 \pm \\
7.40\end{array}$ & $13.33 \pm 8.73$ & $9.23 \pm 6.36$ & 0.506 & 0.040 & 0.295 \\
\hline Lactate & $\begin{array}{l}3.70 \pm \\
6.18\end{array}$ & $3.08 \pm 0.40$ & $3.22 \pm 2.38$ & 0.813 & 0.828 & 0.891 \\
\hline
\end{tabular}

$\mathrm{p}^{\mathrm{a}}$ - difference between COVID-19 RT-PCR positive and COVID-19 RT-PCR negative patients; $\mathrm{p}^{\mathrm{b}}$ difference between COVID-19 RT-PCR positive and non COVID-19 patients; $\mathrm{p}^{\mathrm{C}}$ - difference between COVID-19 RT-PCR negative patients and non COVID-19 patients.

WCC - white cell count; eGFR - estimated glomerular filtration rate; CRP - C Reactive Protein; ALT Alanine Transaminase; ALP - Alkaline Phosphatase; CK - Creatine Kinase; INR - International Normalised Ratio; PT - Prothrombin Time; APTT - activated partial thromboplastin time

\section{Discussion}


This is the first single centre report on COVID-19 related diabetic emergencies. Some of the data in this study was part of the 3 centre study which was published in Lancet Diabetes and Endocrinology recently (12). We have observed that these diabetic patients are profoundly unwell from their diabetic emergencies, with COVID-19 swab negative patients seemingly having greater metabolic disturbance. This could be related to the levels of viraemia, however this analysis did not have access to any investigations that can accurately quantify this. During their admission, all patients received fluid and insulin therapy as per the DKA or HHS protocols for the trust, with no deviation in patients that also received treatment for COVID-19.

Most of the results did not achieve statistical significance due to the relatively low number of subjects in each arm. Of interest in this study is that the percentage of people of African and Asian ethnicity who presented with diabetic emergencies, especially ketosis/ketoacidosis. The other interesting observation is the length of time required for ketone resolution was 43 hours for COVID-19 positive cases as opposed to 23-27 hours for COVID-19 negative patients, even though this was statistically not significant.

The Kaplan-Meier curve (Fig. 1) demonstrated a clear difference in mortality between COVID-19 patients and the non-COVID-19 cohort. Interestingly, the RT-PCR group had the worst outcomes which correlates to the greater metabolic dysfunction observed. Though given that these Kaplan-Meier curves were only drawn for 7 days following diagnosis as patients were lost to follow up, it is difficult to ascertain any further effect on the patients. This perceived difference between RT-PCR positive and negative patients may also be due to the efficacy of the swab result itself as some were treated on clinical grounds for COVID-19. Larger studies would be able to address this issue.

The very high admission $\mathrm{HbA1c}$ in all groups suggest poor control in all arms. This points to the importance of good glycaemic control to prevent mortality and morbidity. North Middlesex Hospital serves two of the very deprived boroughs of London and the high HbA1c observed in this study reflects the need for better education, awareness and the need for more resource allocation for effective glycaemic control in the population served.

Another interesting observation is the high serum creatinine and corresponding low eGFR in clinically COVID-19 subjects (PCR positive and negative) as opposed to COVID-19 negative patients. This correlates with the observation that Acute Kidney Injury (AKI) is more often observed in this cohort (13). There was no difference in liver function tests unlike previous published trials (14). C-reactive protein (CRP) was elevated in RT-PCR positive patients as opposed to the other groups, though again not statistically significant.

Our choice of COVID-19 markers included ferritin, lactate dehydrogenase, C Reactive Protein and lymphocytes as indicators of COVID-19 disease severity. This was based on a retrospective study from Wuhan, the region of China first affected by COVID-19 (15). Our patients show elevated levels of these markers, with marginally reduced lymphocyte count, suggesting that there is severe metabolic derangement - however whether this is due to COVID-19, the diabetic emergency or a combination is yet to be determined. Similarly, the COVID-19 markers used at our centre are non-specific and can be elevated 
purely from a diabetic emergency point of view. Unfortunately, during this period the investigation of possible COVID-19 with certain biomarkers was not within an established protocol meaning that some patients did not have all investigations performed.

\section{Limitations}

Our study was small $(n=30)$ which makes statistical analyses difficult and can lead to false significance. However, the findings of our retrospective analysis are corroborated by both Bornstein et al (5) and the Diabetes UK guidelines (6) whose recommendations are in line with our findings.

One other key factor of our analysis revolves around the COVID-19 RT-PCR swab status. 21 patients were treated for COVID-19 and a diabetic emergency during their admission regardless of swab status. Issues regarding the reliability of the COVID-19 swabs are known, with high proportion of false negatives and need for interpreting results with caution $(16,17)$. However, the only way to date to successfully test for COVID-19 is by RT-PCR of nasal swab, tracheal aspirate or bronchoalveolar lavage samples (18). There are many barriers to the rapid roll out of serological tests including assessment of sensitivity and specificity of the tests, possibility of false positive tests due to cross-reactivity with other viral pathogens and ensuring that mass production of the test is economically viable (19). Another key limitation of this report is that this is a retrospective analysis of routinely collected data, meaning that there are some gaps in investigations. These primarily included Lactate dehydrogenase, ferritin and aspartate transaminase in the non COVID-19 patients and some of the patients treated during the COVID-19 pandemic.

\section{Conclusion}

We present a single centre observational analysis of COVID-19 patients who suffered from a diabetic emergency, in comparison to non COVID-19 patients. Some significant differences were found, however further investigations are needed into the relationship of COVID-19 and their impact on diabetic control and the risk of diabetic emergencies. A significant difference in mortality was observed. Prospectively collected data with a larger patient base, including data on COVID-19 markers, could help shed further light on the management of inpatient diabetics with COVID-19.

\section{Abbreviations}

ARDS - Acute Respiratory Distress Syndrome

AKI - Acute Kidney Injury

ALT - Alanine Transaminase

ALP - Alkaline Phosphatase

APTT - activated partial thromboplastin time

CK - Creatine Kinase

COVID-19 - Coronavirus Disease 2019

CRP - C Reactive Protein

Page 12/16 
DKA - Diabetic Ketoacidosis

DM - Diabetes Mellitus

eGFR - estimated glomerular filtration rate

$\mathrm{HbA1c}$ - glycosylated haemoglobin

HCO3- - Serum bicarbonate

HHS - Hyperosmolar Hyperglycaemic State

INR - International Normalised Ratio

PCR - Polymerase Chain Reaction

PT - Prothrombin Time

RT-PCR - Reverse Teranscriptase Polymerase chain reaction

Sars CoV 2 - Severe Acute Respiratory Syndrome Coronavirus 2

WCC - white cell count

\section{Declarations}

\section{Contributions}

TJ assisted with data collection and prepared the manuscript. EC, SQ and MZ assisted with data collection and provided comments on iterations of the manuscript. GR and CN provided comments on iterations of the manuscript. RM supervised the project and provided comments on all iterations of the manuscript.

\section{Funding}

No funding was received by any author for the production of this work

\section{Declarations of Interest}

Nothing to declare by any author

\section{Availability of data and materials}

Available from authors on reasonable request

\section{Acknowledgements}

Not applicable

\section{Ethics Approval and Consent to Participate}

We followed the NHS REC decision flowchart and in line with this guidance ethical approval was not sought. The NHS REC flowchart can be found at http://www.hra-decisiontools.org.uk/ethics/ 
We felt that this vital information should be shared with the wider medical community and so a manuscript was prepared and submitted to BMC. Consent was not sought at the time of patient admission as they were not being enrolled into any study. This was part of a clinical audit registered with the trust for review of paper notes. All patient healthcare data were collected anonymously, retrospectively and no patient identifiable data were collected or described in the manuscript. This was in line with the NHS Health Research Authority guidance.(11)

\section{References}

1. Du R-H, Liang L-R, Yang C-Q, Wang W, Cao T-Z, Li M, et al. Predictors of Mortality for Patients with COVID-19 Pneumonia Caused by SARS-CoV-2: A Prospective Cohort Study. European Respiratory Journal. 2020 Jan 1;55(5).

2. Barron E, Bakhai C, Kar P, Weaver A, Bradley D, Ismail H, et al. Associations of type 1 and type 2 diabetes with COVID-19-related mortality in England: a whole-population study. The Lancet Diabetes \& Endocrinology. 2020 Oct 1;8(10):813-22.

3. Yang JK, Feng Y, Yuan MY, Yuan SY, Fu HJ, Wu BY, et al. Plasma glucose levels and diabetes are independent predictors for mortality and morbidity in patients with SARS. Diabet Med. 2006 Jun;23(6):623-8.

4. Huang I, Lim MA, Pranata R. Diabetes mellitus is associated with increased mortality and severity of disease in COVID-19 pneumonia - A systematic review, meta-analysis, and meta-regression. Diabetes Metab Syndr. 2020 Apr 17;14(4):395-403.

5. Bornstein SR, Rubino F, Khunti K, Mingrone G, Hopkins D, Birkenfeld AL, et al. Practical recommendations for the management of diabetes in patients with COVID-19. The Lancet Diabetes \& Endocrinology. 2020 Apr 23;8(6):546-50.

6. Rayman PG, Lumb DA, Kennon DB, Cottrell C, Nagi DD, Page E, et al. COncise adVice on Inpatient Diabetes (COVID:Diabetes): FRONT DOOR GUIDANCE.

7. Rawla P, Vellipuram AR, Bandaru SS, Pradeep Raj J. Euglycemic diabetic ketoacidosis: a diagnostic and therapeutic dilemma. Endocrinol Diabetes Metab Case Rep. 2017 Sep 4;2017.

8. Cariou B, Hadjadj S, Wargny M, Pichelin M, Al-Salameh A, Allix I, et al. Phenotypic characteristics and prognosis of inpatients with COVID-19 and diabetes: the CORONADO study. Diabetologia. 2020 May 29;1-16.

9. Hussain A, Bhowmik B, Cristina do Vale Moreira N. COVID-19 and Diabetes: Knowledge in Progress. Diabetes Res Clin Pract [Internet]. 2020 Apr 9 [cited 2020 Apr 25]; Available from: https://www.ncbi.nlm.nih.gov/pmc/articles/PMC7144611/

10. COVID-19: investigation and initial clinical management of possible cases [Internet]. GOV.UK. [cited $2020 \mathrm{Jul}$ 21]. Available from: https://www.gov.uk/government/publications/wuhan-novelcoronavirus-initial-investigation-of-possible-cases/investigation-and-initial-clinical-management-ofpossible-cases-of-wuhan-novel-coronavirus-wn-cov-infection 
11. Consent in research [Internet]. Health Research Authority. [cited 2020 Dec 19]. Available from: https://www.hra.nhs.uk/planning-and-improving-research/policies-standards-legislation/dataprotection-and-information-governance/gdpr-guidance/what-law-says/consent-research/

12. Armeni E, Aziz U, Qamar S, Nasir S, Nethaji C, Negus R, et al. Protracted ketonaemia in hyperglycaemic emergencies in COVID-19: a retrospective case series. The Lancet Diabetes \& Endocrinology. 2020;8(8):660-3.

13. Ronco C, Reis T, Husain-Syed F. Management of acute kidney injury in patients with COVID-19. The Lancet Respiratory Medicine. 2020 Jul 1;8(7):738-42.

14. Bertolini A, Peppel IP van de, Bodewes FAJA, Moshage H, Fantin A, Farinati F, et al. Abnormal liver function tests in COVID-19 patients: relevance and potential pathogenesis. Hepatology. 72(5):186472.

15. Zhou F, Yu T, Du R, Fan G, Liu Y, Liu Z, et al. Clinical course and risk factors for mortality of adult inpatients with COVID-19 in Wuhan, China: a retrospective cohort study. Lancet. 2020 28;395(10229):1054-62.

16. Tahamtan A, Ardebili A. Real-time RT-PCR in COVID-19 detection: issues affecting the results. Expert Rev Mol Diagn. 2020 Apr 22;0(0):1-2.

17. Watson J, Whiting PF, Brush JE. Interpreting a covid-19 test result. BMJ. 2020;369:m1808.

18. Pascarella G, Strumia A, Piliego C, Bruno F, Del Buono R, Costa F, et al. COVID-19 diagnosis and management: a comprehensive review. J Intern Med. 2020 Apr 29;

19. Winter AK, Hegde ST. The important role of serology for COVID-19 control. Lancet Infect Dis. 2020 Apr 21;20(7):758-9.

\section{Figures}




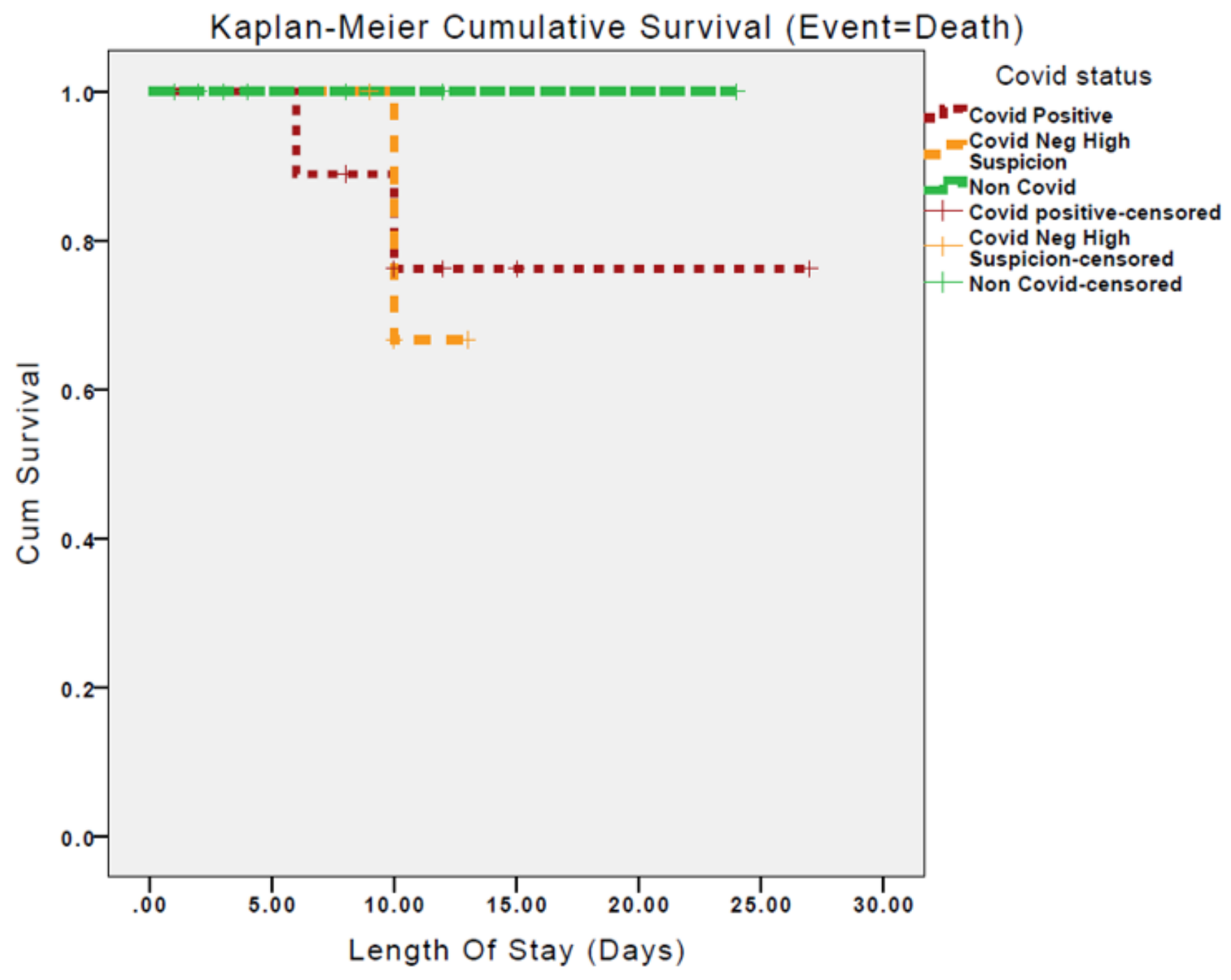

Figure 1

Kaplan Meier Survival Curves between RT-PCR positive, RT-PCR negative and non-COVID-19 patients during their admission. 